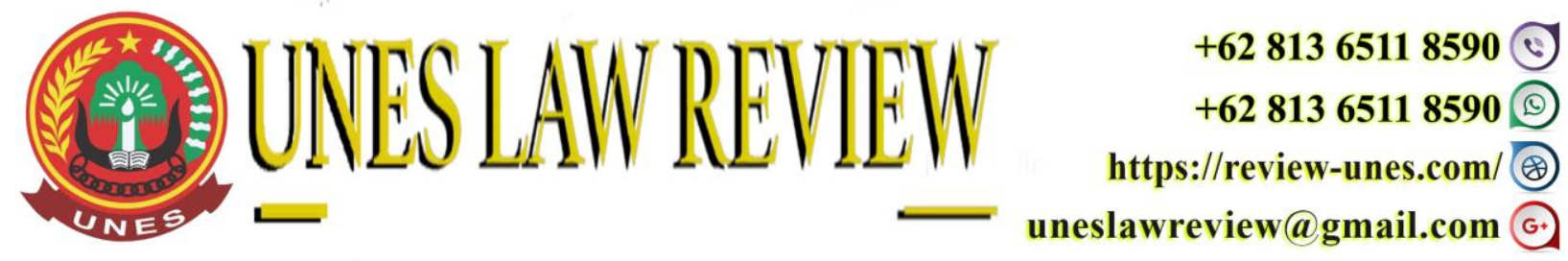

DOI: https://doi.org/10.31933/unesrev.v4i2

Diterima: 20/11/2021, Diperbaiki: 06/12/2021, Diterbitkan: 10/12/2021

\title{
KONSEP CYBERBULLYING DALAM PERSPEKTIF HUKUM PIDANA
}

\section{Hariyanto}

Magister Ilmu Hukum, Fakultas Hukum, Universitas Mataram, Indonesia.

Email: fh.hariyanto17@gmail.com

Corresponding Author: Hariyanto

\section{ABSTRACT}

This research is a normative legal research that aims to analyze the modus operandi of cyberbullying and analyze cyberbullying in the perspective of criminal law in Indonesia and other countries. The method in this study is a normative research method. The results of the study analyzed that the modus operandi of cyberbullying is various forms of bullying or bullying that is carried out through the internet. The modus operandi can be categorized into exclusion; flaming; impersonation/fake profiles; trickery; fraping; dissing; and cyberstalking. In Indonesia, cyberbullying is still not specifically regulated or limited. So the handling still depends on Law Number 19 of 2016 concerning Electronic Information and Transactions. Likewise in the Criminal Code the crime of cyberbullying is only limited to insults and defamation. An adequate discussion regarding cyberbullying is contained in Arkanas Regulation (AR Code) AR Code 571-217 (2015) in points (b), (c) and (d) as well as in the EU's Criminal Law in Conclusion of the Council 2009/C62 /05 of 27 November 2008 and the 2011/92/EU Directive on combating inappropriate treatment in cyberspace.

Keywords: Cyberbullying, Criminal Law Perspective.

\begin{abstract}
ABSTRAK
Penelitian ini meruakan penelitian hukum nrmatif yang bertujuan untuk menganalisis modus operandi kejahatan cyberbullying serta menganalisis cyberbullying dalam perspektif hukum pidana di indonesia dan negara lain. Metode dalam penelitian ini merupakan metode penelitian normayif. Hasil dari penelitian dianalisis bahwa modus operandi dari kejahatan cyberbullying merupakan berbagai bentuk bullying atau perundungan yang dilakukan melalui media internet. Modus perandi tersebut dapat dikategorikan menjadi exclusion; flaming; impersonation/fake profile; trickery; fraping; dissing; dan cyberstalking. Di indonesia Cyberbullying masih belum diatur secara khusus atau limitatif. Sehingga penanganannya masih bergantung pada Undangundang Nomor 19 Tahun 2016 tentang Informasi dan Transaksi Elektronik. Begitupun di dalam KUHP kejahatan cyberbullying hanya terbatas pada penghinaan dan pencemaran nama baik. Pembahasan mengenai cyberbullying cukup memadai terdapat dalam Arkanas Regulation (AR
\end{abstract}


Code) AR Code § 5-71-217 (2015) pada point (b), (c) dan (d) begitupan dalam EU's Criminal Law pada Conclusion of the Council 2009/C62/05 pada tanggal 27 November 2008 dan Arahan 2011/92/UE tentang memerangi perlakuan yang tidak pantas di dunia maya.

Kata Kunci: Cyberbullying, Perspektif Hukum Pidana.

\section{PENDAHULUAN}

Cyberbullying merupakan istilah dari Bahasa Inggris yang sulit untuk didefinisikan. Studi oleh Nocentini menyatakan bahwa terdapat pemahaman yang berbeda dalam penggunaan istilah cyberbullying di beberapa negara. "... Die Ergebnisse zeigten, dass in Deutschland die Bezeichnung "Cyber-Mobbing“, in Italien „Virtual-“ oder „Cyber-Bullying“ und in Spanien „,harrassment via Internet or mobile phone“ ....". " Hasil penelitian menunjukkan bahwa di Jerman digunakan istilah "cyber-bullying", di Italia "virtual" dan di Spanyol "pelecehan melalui Internet atau ponsel". Secara umum cyberbullying merupakan salah satu bentuk cyber crime yang menggunkan komputer maupun Telepon genggam sebagai sebuah alat untuk melakukan tindak kejahatan oleh pelakunya, dan individu sebagai sebagai korban dari tindak kejahatan cyberbullying. ${ }^{2}$

Berdasarkan Cyber Bullying Research Centre, secara singkat cyberbullying didefinisikan sebagai "willful and repeated harm inflicted through the use of computers, cell phones, and other electronic devices. "3 Definisi tersebut cukup komprehensif dan dapat menjelaskan unsurunsur paling penting yang terdapat dalam cyberbullying. Dari kalimat "Computers, cell phones, and other electronic devices" di atas dapat terlihat jelas perbedaan antara cyberbullying dengan bullying tradisional. Pada cyberbullying yang menjadi media untuk melakukan tindakannya adalah komputer, telepon genggam maupun media online lainnya, sehingga cyberbullying merupakan jenis bullying yang sulit dideteksi, dan pelaku sulit dibedakan karena dapat dengan mudah berpose sebagai orang lain. termasuk mengirim surat kebencian, ancaman, komentar seksual, dan memposting hal-hal palsu tentang seseorang untuk mempermalukan korbannya. Sedanhkan intimidasi atau perundungan secara tradisional (tradition bullying) dilakukan secara tatap muka, yaitu korban mengetahui orang yang menindasnya, dalam cyberbullying, pelaku intimidasi dapat menyembunyikan identitasnya yang membuatnya lebih berani dan dapat mengatakan dan melakukan lebih banyak hal yang merusak kepada korban.

Survey yang dilakukan oleh Ipsos Internationel Survei pada 18.687 warga di 24 negara termasuk Indonesia ditemukan bahwa satu dari delapan orang tua menyatakan anak mereka pernah menjadi korban perundungan melalui media online (cyberbullying). Lebih jauhnya

\footnotetext{
${ }^{1}$ Nalaura Nocentini, Juan Calmaestra, Anja Schultze-Krumbholz, Herbert Scheithauer, Rosario Ortega, Ersilia Menesini: Cyberbullying: Labels, Behaviours and Definition in Three European Countries. Journal of Psychologists and Counsellors in Schools. Band 20, Nr. 2, Dezember 2010

${ }^{2}$ Andri Priyatna, Let's End Bullying: Memahami, Mencegah, dan MEngatasi Bullying, PT Elex Media Komputindo, Jakarta, 2010, hlm 32.

${ }^{3}$ Sameer Hinduja \& Justin W. Patchin, 2009, Cyber Bullying Research Center: Cyber Bullying Fact Sheet, What You Need To Know About Online Aggression, hlm. 1 diunduh dari http://www.cyberbullying.us/cyberbullying fact sheet.pdf
} 
penelitian tersebut mengungkap bahwa sebanyak 55\% orang tua menyatakan mereka mengetahui anaknya mengalami perundungan di dunia maya. ${ }^{4}$ Intimidasi secara tradisional maupun perundungan melalui media online (Cyberbullying) memiliki dampak psikologis berupa perasaan sedih bahkan sampai melakukan upaya bunuh diri. ${ }^{5}$ Terlihat jelas betapa pentingnya kejahatan cyberbllying perlu diperhatikan karena memiliki dampak yang bahaya bagi korban. Berdasarkan perasalahan di atas dapat dilihat betapa pentingnya untuk dianalisis tentang "Konsep Cyberbullying Dalam Perspektif Hukum Pidana"

Permasalahan dalam penelitian ini dapat dirumusakan sebagai perikut: Pertama, Bagaimanakah modus operandi dalam kejahatan cyberbullying?; Kedua, Bagaimana kejahatan cyberbullying dari aspek hukum pidana indonesia dan negara lain?

\section{METODE PENELITIAN}

Metode Penelitian yang digunakan dalam penelitian ini adalah penelitian normatif. jenis penelitian hukum ini sering sebut sebagai penelitian hukum doktriner atau penelitian kepustakaan. Dalam penelitian normatif hukum dikonsepkan sebagai apa yang tertulis dalam peraturan perundang-undangan (law in books) atau hukum dikonsepkan sebagai kaidah atau norma. ${ }^{6}$ Metode pendekatan yang digunakan yaitu Pendekatan Perundang-undangan (Statute Approach), dan Pendekatan Konseptual (Conceptual Approach). Bahan hukum yang digunakan dalam penelitian ini berupa bahan hukum Primer dan bahan hukum sekunder. Teknik dan Alat Pengumpulan Bahan Hukum dalam penelitian ini dikumpulkan melalui studi dokumen meliputi bahan hukum primer dan bahan hukum sekunder. Analisis bahan hukum dilakukan dengan cara mengumpulkan bahan hukum dan mengidentifikasinya, maka analisis bahan hukum dilakukan dengan melakukan penafsiran (interpretation) terhadap bahan hukum yang dijadikan dasar. penafsiran yang digunakan adalah karakter hermeneutik, yaitu penafsiran gramatika atau penafsiran menurut tata bahasa; dan penafsiran ekstensif atau penafsiran yang memperluas pengertian atau istilah yang ada dalam udang-undang

\section{HASIL DAN PEMBAHASAN}

\section{Modus Operandi Kejahatan Cyberbullying}

Dalam wikipedia Bahasa Belanda modus operandi diartikan sebagai: Met modus operandi worden de handelingen bedoeld die een crimineel uitvoert om zijn misdaad te begaan. Hierbij wordt gekeken naar de bedoelingen van de handelingen: 1) ervoor zorgen dat de misdaad lukt; 2) het tegengaan van identificatie van de dader; 3) het verkrijgen van een vluchtmogelijkheid of ontsnapping. ${ }^{7}$

\footnotetext{
${ }^{4}$ Cyberbullying facts and statistics for 2018-2021, di akses dari http://www.comparitech.com/internetproviders/cyberbullying-statistics/ pada tanggal 20 Novermber 2021.

${ }^{5}$ Merrill, R. M., \& Hanson, C.L. Risk and Protective Factor Associated with Being Bullied on School Property Compared with Cyberbullied. BMC Public Health, 1-10.

${ }^{6}$ Zainal Asikin \& Amiruddin, Pengantar Metode Penelitian Hukum, Cetakan Kesepuluh, PT Rajagrafindo Persada, Jakarta, 2018, hlm. 165.

${ }^{7}$ Modus operandi diakses dari https://nl.m.wikipedia.org/wiki/Modus_operandi pada tangga; 28 November 2021.
} 
Dari pernyataan di atas, dapat disimpulakn bahwa modus operandi dapat diartikan sebagai tindakan untuk memastikan bahwa kejahatan akan berhasil, mencegah identifikasi pelaku, dan memperoleh sarana untuk melarikan diri.

Jika dilihat dari media yang digunakan, cyberbullying merupakan kejahatan jenis baru. Fenomena ini membutuhkan perhatian khusus dari para penegak hukum karena semakin masifnya interaksi dalam dunia cyber. Untuk mendapatkan pemahaman yang lebih jauh mengenai tindakan serta cara-cara yang digunakan pelaku dalam melakukan kejahatan cyberbullying, berikut akan dijelaskan modus operandi dari kejahatan cyberbullying.

\section{Exclusion}

Sama halnya dengan di dunia nyata, pengecualian (exclusion) di dunia maya dilakukan dengan cara mengata-ngatai, menjelek-jelekkan dan bahkan adu argument yang membuat korban jadi terpojok dan bahkan dikeluarkan dari grup media social tersebut.

Social exclusion is "a multidimensional process of progressive social rupture, detaching groups and individuals from social relations and institutions and preventing them from full participation in the normal, normatively prescribed activities of the society in which they live" 8

Eksklusi sosial adalah "proses multidimensi dari perpecahan sosial yang progresif, memisahkan kelompok dan individu dari hubungan dan institusi sosial dan mencegah mereka dari partisipasi penuh dalam kegiatan normal yang ditentukan secara normatif dari masyarakat tempat mereka tinggal"

Exclution biasanya merupakan tindakan verbal atau eksplisit yang menyatakan bahwa individu tidak diinginkan sebagai anggota dalam suatu hubungan atau kelompok. Pengecualian merupakan tindakan yang disengaja untuk meninggalkan seseorang. Dari konsep exclution yang dikemaukan oleh Silver sebelumnya, penulis mengelompokkan beberapa cara sebagai berikut:

a. Korban dikucilkan atau dikucilkan dari grup media sosial atau kegiatan teman di media sosial.

b. Pelaku melakukan percakapan online dan menandai teman lain tetapi tidak menandai korban sehingga merasa terkucilkan.

c. Korban tidak memiliki ponsel cerdas (smartphone) dan sengaja dikeluarkan dari grup percakapan oleh orang lain karena hal tersbut.

\section{Flaming Harassment}

Flaming merupakan tindakan memposting penghinaan, sering kali termasuk kata-kata kotor atau bahasa kasar lainnya di internet. Flaming muncul dari anonimitas bahwa forum Internet menyediakan perlindungan bagi pengguna untuk bertindak lebih agresif.

Anonymity can lead to disinhibition, which results in the swearing, offensive, and hostile language characteristic of flaming. Lack of social cues, less accountability of face-to-face communications, textual mediation and deindividualization are also likely factors.

Anonimitas dapat menyebabkan rasa malu, yang menghasilkan karakteristik bahasa yang menyakitkan, menyinggung, dan bermusuhan. Kurangnya isyarat sosial, kurang akuntabilitas

\footnotetext{
${ }^{8}$ Silver, H. (2007). Social Exclusion: Comparative Analysis of Europe and Middle East Youth, 2007, Middle East Youth Initiative Working paper. Diakses dari http://www.shababinclusion.org/content/document/detail/558 pada tanggal 01 Desember 2021.
} 
komunikasi tatap muka, mediasi tekstual dan deindividualisasi juga merupakan faktor kemungkinan. ${ }^{9}$

Flaming yang sengaja dilakukan oleh individu yang dikenal sebagai flamers, secara khusus termotivasi untuk memicu perselisihan. Pelaku berspesialisasi dalam memicu perpecahan dan menargetkan aspek-aspek tertentu dari percakapan yang kontroversial. Perilaku tersebut dapat memiliki efek buruk yang dramatis pada orang lain. Perselisihan dapat memiliki dampak yang bertahan lama pada beberapa komunitas internet, bahkan hingga terjadi pembubaran komunitas.

\section{Impersonation and Denigration (Peniruan Identitas dan Pencemaran Nama Baik)}

Penulis menggabungkan dua bentuk perbuatan tersebut karena impersonation selalu berimbas kepada pencemaran nama baik atau denigration. Impersonation adalah tindak peniruan atau penyamaran dengan membuat akun palsu (fake profile) atas nama korbannya bertujuan untuk menjelek-jelekkannya. Sedangkan denigration dapat diartikan sebagai tindakan untuk:

This is when someone may send information about another person that is fake, damaging and untrue. Sharing photos of someone for the purpose to ridicule, spreading fake rumours and gossip. The photos can also be altered for the purpose of bullying. ${ }^{10}$

Denigrasi adalah istilah yang digunakan untuk menggambarkan saat seseorang dapat mengirim informasi tentang orang lain yang palsu, merusak, dan tidak benar. Berbagi foto seseorang dengan tujuan untuk mengejek, menyebarkan rumor dan gosip palsu. Foto-foto juga dapat diubah untuk tujuan bullying.

Berdasarkan hal di atas, dapat dikatakan bahwa tindakn pelaku impersination adalah mengirim, memposting desas-desus kejam, gosip, dan pernyataan palsu atau tidak benar tentang korban untuk dengan sengaja merusak reputasi atau persahabatan korbannya.

\section{Trickery and outing}

Trickery merupakan bentuk cyberbullying yang paling sering terjadi pada wanita. Trickery adalah tindakan menipu seseorang agar memberikan informasi pribadinya berupa foto-foto ataupun video pribadi bahkan tidak jarang wanita membagikan foto ataupun video asusila. Trickery erat kaitannya dengan outing, karena outing merupakan tindakan menyebarkan rahasia orang lain berupa informasi atau foto-foto pribadi seseorang yang telah didapatkan dari tindakan trickery sehingga menimbulkan rasa malu atau depresi kepada korban.

Tindakan trickery biasanya dilakukan dengan perkenalan melalui media sosial sehingga menjalin suatu persahabatan bahkan tidak jarang menjalin hubungan asmara meski tidak pernah bertemu. Hal demikian dimanfaatkan olek pelaku trickery untuk meminta informasi pribadi dan foto-foto pribadi korbannya yang kemudian pelaku membagi atau mempublikasikan informasi pribadi tersbut kepada orang lain.

\footnotetext{
${ }^{9}$ Daegon, Kwon Hazel, "The impacts of identity verification and disclosure of social cues on flaming in online user comments". Computers in Human Behavior. Volume 51 October 2015 ,hlm. 363-372.

${ }^{10}$ Whats is bullying, diakses dari https://www.bullying.co.uk/-cyberbullying/what-is-cyberbullying/ pada tanggal 02 Desember 2021.
} 


\section{Fraping}

Faraping merupakan istilah untuk seseorang yang meretas email atau akun jejaring sosial orang lain dan menggunakan identitas online orang tersebut untuk mengirim atau memposting materi yang kejam atau memalukan tentang orang orang tersebut. Dikatakan oleh Belk bahwa:

In the limitedexisting scholarly literature on fraping, Lumsden and Morgan, associate the phenomenon with antisocial activities of cyberbullying. Outside of academia, politicians and thejudiciary have also interpreted fraping as deeply antisocial. ${ }^{11}$

Dalam literatur ilmiah terbatas yang ada tentang fraping, Lumsden dan Morgan, mengaitkan fenomena tersebut dengan aktivitas antisosial (cyberbullying). Di luar akademisi, politisi dan peradilan juga menafsirkan fraping sebagai tindakan yang sangat antisosial.

Fraping kerap dilakukan oleh teman dekat untuk memposting konten yang tidak pantas dengan nama orang lain. Tindakan fraping sering dianggap sebagai lelucon terhadap teman dengan menulis postingan lucu di profil satu sama lain, tetapi hal demikian berpotensi sangat berbahaya. Misalnya, pelaku intimidasi memposting hinaan rasial/homofobia melalui profil orang lain dengan tujuan untuk bercanda, namun hal demikian dapat merusak reputasi karena membuat orang tersebut dianggap benar-benar telah melakukan perbuatan yang dilakukan oleh peretas.

\section{Dissing}

Dissing adalah tindakan mengirim atau memposting informasi kejam tentang seseorang secara online, untuk merusak reputasi atau persahabatan orang tersebut. Dissing hampir sama dengan impersonation, namun perbedaanya terletak pada tindakan Dissing tidak memakai akun palsu (fake profile) untuk memposting informasi kejam tentang korbannya. Selain memposting informasi kejam, dissing dapat mencakup tindak memposting materi online seperti foto, tangkapan layar (screenshot), amupun video.

\section{Cyber Stalking.}

Cyberstalking adalah penggunaan Internet atau sarana elektronik lainnya untuk menguntit atau melecehkan individu ataupun kelompok. Lebih lengkapnya Sptzberg menyebutkan beberapa modus yang cukup lengkap untuk memahami cyberstalking sebagai berikut:

It include false accusations, defamation, slander and libel. It may also include monitoring, identity theft, threats, vandalism, solicitation for sex, doxing, or blackmail. ${ }^{12}$

Ini (cyberstalking) termasuk tuduhan palsu, pencemaran nama baik, fitnah dan penghinaan. Ini juga dapat mencakup pemantauan, pencurian identitas , ancaman, vandalisme, ajakan untuk berhubungan seks, doxing, atau pemerasan .

Tindakan cyberstalking dimotivasi oleh keinginan untuk mengontrol, mengintimidasi atau mempengaruhi korban. Seorang penguntit mungkin orang asing di dunia maya atau orang yang dikenal oleh target. Dalam menjalankan aksi biasanya dalam bentuk anonim dan meminta keterlibatan orang lain secara online yang bahkan tidak mengetahui targetnya.

\footnotetext{
${ }^{11}$ Belk, R. W. (2013). Extended self in a digital world. Journal of Consumer Research, 40(3), 2013. hlm. 113.

${ }^{12}$ Spitzberg, Brian H.; Hoobler, Gregory "Cyberstalking and the technologies of interpersonal terrorism". New Media \& Society. 1(4) February 2002, hlm. 71-92.
} 


\section{Cyberbullying dari Aspek Hukum Pidana di Indonesia dan Negara Lain}

\section{Cyberbullying dari Aspek Hukum Pidana di Indonesia}

Secara umum Cyberbullying dalam aspek hukum pidana diinterprestasikan terhadap berbagai delik yang diatur dalam hukum pidana umum di Indonesia, yaitu yang termuat dalam Kitab Undang-undang Hukum Pidana (KUHP). Pasal dalam KUHP yang relevan dalam mengatur delik Cyberbullying adalah sebagaimana tercantum dalam Bab XVI mengenai Penghinaan, khusunya Pasal 310 ayat (1) dan ayat (2).

Pasal 310 "Barang siapa dengan sengaja menyerang kehormatan atau nama ayat (1) baik seseorang dengan menuduhkan sesuatu hal, yang maksudnya terang supaya hal itu diketahui umum, diancam karena pencemaran, dengan pidana penjara paling lama sembilan bulan atau pidana denda paling banyak empat ribu lima ratus rupiah".

Pasal 310 "Jika hal itu dilakukan dengan tulisan atau gambaran yang ayat (2) disiarkan, dipertunjukan atau ditempelkan dimuka umum, maka diancam karena pencemaran tertulis dengan pidana penjara paling lama satu tahun empat bulan atau pidana denda paling banyak empat ribu lima ratus rupiah".

Pada dasarnya, KUHP memang dibentuk jauh sebelum perkembangan teknologi dunia maya. Ketentuan pidana dalam KUHP untuk Cyberbullying sangat sedikit dan tidak sesuai dengan intimidasi, pelecehan atau perlakuan kasar secara verbal secara terus menerus yang dilakukan di dunia maya pada masa sekarang. Maka, dalam rangka mengakomodasi pengaturan mengenai dunia maya dan segala hal yang berkaitan dengannya, dibentuk Undang-undang Nomor 19 Tahun 2016 tentang Informasi dan Transaksi Elektronik.

Dengan dikeluarkan dan diberlakukannya Undang-undang Nomor 19 Tahun 2016 Tentang Perubahan atas Undang-undang Nomor 11 Tahun 2008 Tentang Informasi dan Transaksi Elektronik, maka pengelolahan, penggunaan dan pemanfaatan informasi dan transaksi elektronik harus terus dikembangkan melalui infrastuktur hukum dan pengaturannya sehingga pemanfaatannya dengan memperhatikan nilai-nilai agama, sosial dan budaya masyarakat Indonesia, serta untuk menjaga, memelihara dan memperkukuh persatuan dan kesatuan nasional berdasarkan peraturan perundang-undangan demi kepentingan nasional. Perbuatan yang dilarang mengenai tindak kejahatan perundungan dunia maya (cyberbullying) diatur dalam BAB VII PERBUATAN YANG DILARANG dalam Undang-undang Nomor 11 Tahun 2008 jo. Undangundang Nomor 19 Tahun 2016 tentang Informasi dan Transaksi Elektronik yaitu :

Pasal 27 1) Setiap Orang dengan sengaja dan tanpa hak mendistribusikan dan/atau mentransmisikan dan/atau membuat dapat diaksesnya Informasi Elektronik dan/atau Dokumen Elektronik yang memiliki muatan yang melanggar kesusilaan.

3) Setiap Orang dengan sengaja dan tanpa hak mendistribusikan dan/atau mentransmisikan dan/ataumembuat dapat diaksesnya 
Informasi Elektronik dan/atau Dokumen Elektronik yang memiliki muatan penghinaan dan/atau pencemaran nama baik.

4) Setiap Orang dengan sengaja dan tanpa hak mendistribusikan dan/atau mentransmisikan dan/atau membuat dapat diaksesnya Informasi Elektronik dan/atau Dokumen Elektronik yang memiliki muatan pemerasan dan/atau pengancaman.

Pasal 28 2) Setiap Orang dengan sengaja dan tanpa hak menyebarkan informasi yang ditujukan untuk menimbulkan rasa kebencian atau permusuhan individu dan/atau kelompok masyarakat tertentu berdasarkan atas suku, agama, ras, dan antargolongan (SARA).

Pasal 29 Setiap Orang dengan sengaja dan tanpa hak mengirimkan Informasi Elektronik dan/atau Dokumen Elektronik yang berisi ancaman kekerasan atau menakut-nakuti yang ditujukan secara pribadi.

Seperti yang dipaparkan sebelumnya, peraturan perundang-undangan di indonesia terhadap kasus Cyberbullying masih belum diatur secara khusus atau limitatif. Sehingga penanganannya masih bergantung pada Undang-undang Nomor 19 Tahun 2016 tentang Informasi dan Transaksi Elektronik. Begitupun di dalam KUHP kejahatan cyberbullying hanya terbatas pada penghinaan dan pencemaran nama baik.

\section{Cyberbullying dari aspek hukum pidana di Negara Lain}

\section{a. Arkanas Regulation (AR Code)}

Beberapa Negara telah mengatur secara eksplisit mengenai cyberbullying. Contohnya di Negara bagian Amerika Serikat yakni Arkansas, pada AR Code § 5-71-217 (2015) pada point (b), (c) dan (d) mengatur mengenai cyberbullying, pada point-pointnya menyebutkan:

AR Code A person commits the offense of cyberbullying if:

1) He or she transmits, sends, or posts a communication by electronic means with the purpose to frighten, coerce, intimidate, threaten, abuse, or harass another person; and

2) The transmission was in furtherance of severe, repeated, or hostile behavior toward the other person.

AR Code The offense of cyberbullying may be prosecuted in the county where the defendant was located when he or she transmitted, sent, or posted a communication by electronic means, in the county where the communication by electronic means was received by the person, or in the county where the person targeted by the electronic communications 
resides.

AR Code Cyberbullying is a Class B misdemeanor.

1) Cyberbullying is a Class B misdemeanor.

2) Cyberbullying is a Class A misdemeanor if the victim is a school employee. ${ }^{13}$

Dari rumusan AR Code § 5-71-217 (2015) di atas Point (b) menjelaskan yang temasuk pelanggaran cyberbullying apabila melakukan: (1) seseorang yang mentransmisikan, mengirim, atau memposting komunikasi melalui sarana elektronik dengan tujuan untuk menakut-nakuti, memaksa, mengintimidasi, mengancam, menyalah-gunakan, atau melecehkan orang lain; dan (2) Penularan itu merupakan kelanjutan dari perilaku yang parah, berulang, atau bermusuhan terhadap orang lain

Pada point (c) Pelanggaran cyberbullying dapat dituntut di negara tempat terdakwa berada ketika dia mengirimkan, mengirim, atau memasang komunikasi melalui sarana elektronik, di negara tempat komunikasi melalui sarana elektronik diterima oleh orang tersebut, atau di daerah tempat orang yang menjadi sasaran komunikasi elektronik itu tinggal. Dan terakhir point (d) dijelaskan pada bagian (1) Cyberbullying adalah pelanggaran Kelas B. (2) Cyberbullying merupakan pelanggaran Kelas A jika korbannya adalah pegawai sekolah.

\section{b. EU's Criminal Law}

Uni Eropa memiliki peraturan yang cukup memadai dalam menangani masalah cyberbullyingi, Strategi Komisi Eropa tentang memerangi cyberbullying tertuang dalam Conclusion of the Council 2009/C62/05 pada tanggal 27 November 2008 dan Arahan 2011/92/UE tentang memerangi perlakuan yang tidak pantas di dunia maya dengan tujuan seksual dan pelecehan seksual terhadap anak dan pornografi anak.

Yang menarik di Uni Eropa adalah Arahan 2002/58/WE tentang privasi dan komunikasi elektronik, dalam arahan tersebut mewajibkan penyedia layanan Internet untuk memberikan keamanan layanan. Arahan tersebut ditetapkan dalam Komunikasi Komisi Eropa, Dewan dan Komite of Regions pada tahun 2007 dengan judul "Towards an EU strategy of combating cyberbullying" dalam bahasa indonesia dapat berarti "Menuju strategi Uni Eropa memerangi cyberbullying". Beberapa modus kejahatan dunia maya yang disebutkan dalam Communication KOM(2007) 267 on 22 May 2007 adalah sebagai berikut:

1) Traditional computer-related crimes, including molesting children;

2) Crime content including child pornography, giving criminal instructions, offering to commit crimes, molesting, lobbying via the internet, spreading false information;

3) Other legal acts, referring to certain criminal matters, including regulations regarding the unauthorized use of the Internet. ${ }^{15}$

\footnotetext{
${ }^{13}$ AR Code $\$$ 5-71-217 (2015) di akses dari https://law.justia.com/-codes/arkansas/2015/title-5/subtitle-6/chapter71/subchapter-2/section-5-71-217 pada tanggal 28 November 2021.

${ }^{14}$ Lihat EU's Communication KOM(2007) 267 on 22 May 2007.

${ }^{15}$ EU's Communication. Op. Cit.
} 
1) Kejahatan tradisional yang berhubungan dengan komputer, termasuk menganiaya anak-anak;

2) Kejahatan konten termasuk pornografi anak, memberikan instruksi kriminal, menawarkan untuk melakukan kejahatan,menganiaya, melobi melalui internet, menyebarkan informasi palsu;

3) Perbuatan hukum lainnya, mengacu pada masalah pidana tertentu, termasuk peraturan tentang penggunaan yang tidak sah melalui Internet.

Arahan di atas sebenarnya lebih khusus terhadap cyberbullying terhadap anak, secara umum pengaturan cyberbullying terdapat dalam Strategi Komisi Eropa pada 28 November 2008 tentang pemberantasan cyberbullying. ${ }^{16}$ Dalam Strategi tersut merekomendasikan untuk melakukan berbagai pengukuran operasional dalam kegiatan internet, dan membentuk tim yang disebut "Cyberpatrols" atau tim investigasi umum terhadap kejahatan cyberbullying dan menerapkan pencarian jarak jauh (remote searching) di Internet.

\section{KESIMPULAN}

Modus operandi dari kejahatan cyberbullying merupakan berbagai bentuk bullying atau perundungan yang dilakukan melalui media internet. Modus perandi tersebut dapat dikategorikan menjadi exclusion atau tindakan pengecualian; flaming atau tindakan momposting penghinaan seperti kata-kata kotor; impersonation atau tindakan penyamaran menggunakan akun palsu (fake profile); trickery atau tindakan untuk menipu seseorang agar memberikan informasi pribadi berupa foto dan video; fraping atau tindakan meretas akun media sosial orang lain; dissing atau tindakan memposting informasi kejam tentang seseorang untuk merusak reputasi; cyberstalking atau tindakan menyerang mental secara berulang-ulang untuk mengganggu kehidupan orang tersebut.

Peraturan perundang-undangan di indonesia terhadap Cyberbullying masih belum diatur secara khusus atau limitatif. Sehingga penanganannya masih bergantung pada Undang-undang Nomor 19 Tahun 2016 tentang Informasi dan Transaksi Elektronik. Begitupun di dalam KUHP kejahatan cyberbullying hanya terbatas pada penghinaan dan pencemaran nama baik. Pembahasan mengenai cyberbullying cukup memadai terdapat dalam Arkanas Regulation (AR Code) AR Code § 5-71-217 (2015) pada point (b), (c) dan (d) begitupan dalam EU's Criminal Law pada Conclusion of the Council 2009/C62/05 pada tanggal 27 November 2008 dan Arahan 2011/92/UE tentang memerangi perlakuan yang tidak pantas di dunia maya.

\section{DAFTAR PUSTAKA}

Andri Priyatna.2010. Let's End Bullying: Memahami, Mencegah, dan MEngatasi Bullying, PT Elex Media Komputindo, Jakarta, 2010.

Zainal Asikin \& Amiruddin. 2018. Pengantar Metode Penelitian Hukum, Cetakan Kesepuluh, PT Rajagrafindo Persada, Jakarta, 2018.

\footnotetext{
${ }^{16}$ Council conclusions of 27 November 2008 on a concerted work strategy and practical measures against cybercrime, Journal of Laws. on 17(03), 2009, hlm. 217-225
} 
Belk, R. W. (2013). Extended self in a digital world. Journal of Consumer Research, 40(3), 2013.

Council conclusions of 27 November 2008 on a concerted work strategy and practical measures against cybercrime, Journal of Laws. on 17(03), 2009.

Daegon, Kwon Hazel. 2015. The impacts of identity verification and disclosure of social cues on flaming in online user comments. Computers in Human Behavior. Volume 51 October 2015.

Nalaura Nocentini, Juan Calmaestra, Anja Schultze-Krumbholz, Herbert Scheithauer, Rosario Ortega \& Ersilia Menesini. 2010. Cyberbullying: Labels, Behaviours and Definition in Three European Countries. Journal of Psychologists and Counsellors in Schools. Band 20, Nr. 2, Dezember 2010.

Merrill, R. M., \& Hanson, C.L. 2010. Risk and Protective Factor Associated with Being Bullied on School Property Compared with Cyberbullied. BMC Public Health, 1(10) 2010.

Spitzberg, Brian H.; Hoobler, Gregory. 2002 "Cyberstalking and the technologies of interpersonal terrorism". New Media \& Society. 1(4) February 2002.

Silver, H. (2007). Social Exclusion: Comparative Analysis of Europe and Middle East Youth, 2007, Middle East Youth Initiative Working paper. Diakses dari http://www.shababinclusion.org/content/document/detail/558 pada tanggal 01 Desember 2021.

AR Code § 5-71-217 (2015) di akses dari https://law.justia.com/-codes/arkansas/2015/title5/subtitle-6/chapter-71/subchapter-2/section-5-71-217 pada tanggal 28 November 2021.

Cyberbullying facts and statistics for 2018-2021, di akses dari http://www.comparitech.com/internet-providers/cyberbullying-statistics/ pada tanggal 20 Novermber 2021.

EU's Communication KOM(2007) 267 on 22 May 2007.

Whats is bullying, diakses dari https://www.bullying.co.uk/-cyberbullying/what-is-cyberbullying/ pada tanggal 02 Desember 2021.

Modus operandi diakses dari https://nl.m.wikipedia.org/wiki/-Modus_operandi pada tangga; 28 November 2021.

Sameer Hinduja \& Justin W. Patchin. 2009. Cyber Bullying Research Center: Cyber Bullying Fact Sheet, What You Need To Know About Online Aggression, hlm. 1 diunduh dari http://www.cyberbullying.us/-cyberbullying_fact_sheet-.pdf 